\title{
Lumen
}

Selected Proceedings from the Canadian Society for Eighteenth-Century Studies

\section{The Meeting of Minds: Lady Mary Wortley Montagu and Louise D'Epinay: French and English Approaches to Girls' Education}

\section{Rosena Davison}

Volume 15, 1996

URI : https://id.erudit.org/iderudit/1012473ar

DOI : https://doi.org/10.7202/1012473ar

Aller au sommaire du numéro

Éditeur(s)

Canadian Society for Eighteenth-Century Studies / Société canadienne d'étude du dix-huitième siècle

ISSN

1209-3696 (imprimé)

1927-8284 (numérique)

Découvrir la revue

Citer cet article

Davison, R. (1996). The Meeting of Minds: Lady Mary Wortley Montagu and Louise D'Epinay: French and English Approaches to Girls' Education. Lumen, 15, 57-70. https://doi.org/10.7202/1012473ar 


\section{The Meeting of Minds: Lady Mary Wortley Montagu and Louise D'Epinay: French and English Approaches to Girls' Education}

In October 1753, Lady Mary Wortley Montagu wrote to her daughter Lady Bute:

We are educated in the grossest ignorance, and no art omitted to stiffle [sic] our natural reason; if some few get above their Nurses' instruction, our knowledge must rest conceal'd and be as useless to the World as Gold in the Mine (III:40). ${ }^{1}$

In 1771 Mme Louise d'Epinay wrote from Paris to her friend and correspondent in Naples, the abbé Galiani:

The truth is, I am very ignorant. My entire education taught me merely the art of pleasing... Even the wisest woman can only acquire the most superficial knowledge. ... Women are therefore reduced to learning music, dancing and poetry. $^{2}$

These letters illustrate the dissatisfaction felt by many women in England and France concerning the inadequate education they received, and demonstrate a growing frustration with the restrictions placed on women as a result of their lack of training. In this paper we shall examine the attempts made by these two writers to draw attention to these restrictions, to devise methods they deemed appropriate for educating women, at least initially within the family circle, and to explain why such an education is necessary for women.

Louise d'Epinay (1726-83) was a member of the well-to-do Parisian bourgeoisie, rarely leaving Paris except for a two-year stay in Geneva; she died at the age of fifty-seven after publishing her few works anonymously, and today is known primarily as the author of semi-fictitious memoirs, and as a friend of Rousseau, Diderot and Voltaire. ${ }^{3}$ Lady Mary Wortley Montagu (1689-1762) was an aristocrat, daughter of Evelyn Pierrepont, first Marquess of Dorchester, later Earl then Duke of King- 
ston; she travelled extensively, even lived abroad for many years and was already known as a writer during her long lifetime. A friend of Alexander Pope, she received warm praise for her Turkish Embassy Letters (published posthumously in 1763) from Gibbon, Johnson, Smollett and especially from Voltaire, who had commended her ${ }^{4}$ in his Lettres philosophiques for introducing inoculation to England, and 'did her the singular honour of giving her in manuscript his essay on epic poetry for comment. ${ }^{5}$ Very much at home in the French language, Lady Mary made the first adaptation and translation into English of Marivaux's Jeu de l'amour et du hasard.

In spite of these differences in background, both women shared a fervent belief in the necessity and value of education, in particular of education for girls, all the more so since it was given such low priority, if not ignored completely, in both England and France in the early part of the eighteenth century. Since their ideas on education are less well known than their other work, it is important to look first at the circumstances which prompted them to express opinions so contrary to accepted norms.

Both writers were for the most part self-taught, but not by choice, and their inadequate formal education only served to strengthen their resolve to improve educational opportunities for future generations of women. Mme d'Epinay acquired her education almost accidentally from the tutors hired to teach her cousins with whom she and her mother were obliged to live after her father's death. After Lady Mary lost her mother at the age of three, she was brought up somewhat haphazardly by her father and grandmother; her education was left to a governess who gave her what she later termed 'the worst education in the world' by filling her head with superstitious tales and false notions. ${ }^{6}$ Both women used whatever educational means were available to them such as friends, mentors, and in Lady Mary's case the considerable resources of her father's library, to satisfy her 'passion for learning' (III:23). An avid reader, she absorbed books in English and French, then Latin, followed by Spanish and Italian. But she also had to learn the various duties of hostess in her father's house: one compensation was that she met such distinguished writers as Addison, Steele and Congreve. This is how one writer recently described her situation:

It was a time when politics and letters knew no division but lived off each other, creating an urbane, sophisticated, anti-romantic and even cynical literature that delighted in witticism, satire and innuendo. A less confident or ambitious girl might have found such company overwhelming but clearly Lady Mary found herself a match for it. ${ }^{7}$ 
Mme d'Epinay's real education began as an adult in the company of Rousseau, Diderot, Voltaire and especially Grimm, who did much to improve her self-esteem and foster her creative talents by entrusting her with his Correspondance littéraire during his frequent absences from Paris: between 1770 and 1775 she wrote more than forty pieces of literary criticism and reviews.

It was a particular concern about their grandaughters which inspired the two writers' decision to focus on girls' education at that time. Mme d'Epinay devoted several years to writing a book dedicated to and inspired by her grandaughter Emilie whom she brought up from the age of two: entitled Conversations d'Emilie, it is based on a series of almost daily encounters with Emilie from the age of five to ten. Two subsequent books were planned, encompassing the ages of ten to fifteen and then fifteen up to the time of marriage, but ill-health and her premature death in 1784 from cancer (also the cause of Lady Mary's death in 1762) prevented her from completing them. Lady Mary's ideas are contained in letters she sent from Italy between 1750 and 1758 to her daughter Lady Bute, whose husband, an impecunious Scottish peer, later became Prime Minister of England.

Mme d'Epinay had already given much thought to pedagogical methods: in 1758 she published two short texts outlining her plans for her own children's education, ${ }^{8}$ these ideas were considerably modified and expanded for Emilie in 1774 and again in 1781, when she published a much longer revised version of the Conversations. But still dissatisfied with the result, Mme d'Epinay continued to lament her lack of experience, questioned her own pedagogical methods and even admitted to Emilie her doubts concerning the advantages of private over public education. ${ }^{9}$ Prior to her letters to her daughter, Lady Mary had not published anything specifically on the subject of education, and yet her comments demonstrate that she had given much thought to it.

Each writer showed concern not just for her grandaughter's accomplishments but also for her happiness, the two being inextricably linked in their opinion. Mme d'Epinay's conviction that the key to a girl's happiness lay in the acquisition of knowledge is echoed by Lady Mary's assertion that

Learning is necessary to the Happiness of Women, and ignorance the common foundation of their Errors, both in Morals and Conduct. (III:83)

Moral issues are of the utmost concern. Frequently expressed is the fear that without learning the resulting boredom could have a devastating effect on the moral reputation of the young person. 'Idleness ... is the mother of mischief' declares Lady Mary, ${ }^{10}$ and Mme d'Epinay writes: 
'Naturally [learning] is the surest and most efficient cure for idleness, which is the most formidable enemy of happiness and virtue'. ${ }^{11}$

But how is one to achieve this goal, given that (as Lady Mary claims) 'Men fancy[ing] the improvement of our understandings would only furnish us with more art to deceive them' ${ }^{12}$ Each recognizes that the acquisition of knowledge is imperative for women and yet it is condemned by society as a source of ridicule or deceit, so ways must be found to circumvent these criticisms. Faced with this dilemma, both Lady Mary and Mme d'Epinay realised that the solution lay in discretion, humility, even dissimulation, but above all, in not flaunting one's learning, 'our knowledge must rest concealed', Lady Mary concluded. In fact she went as far as to recommend that her grandaughter 'conceal whatever learning she attains, with as much solicitude as she would hide crookedness or lameness. The parade of it can only serve to draw on her the envy, and consequently the most inveterate hatred, of all ... fools' (III:22). Mme d'Epinay's approach was slightly less emphatic but she still noted that the display of learning was inappropriate for a girl: when asked by Emilie to explain why certain guests at a party were making fun of a woman who appeared very knowledgeable, she explained that they were mocking the way she was showing off her knowledge:

Genuinely learned people never speak about their knowledge at a social gathering ... they are happy to keep it in their heart, and rarely have it on their lips ... learning has a much greater and more noble objective than that of an empty display of knowledge ("une vaine ostentation de science") (12th Conversation, I:463-6).

What fields of knowledge were considered essential to provide a good education for girls? Both writers recommended a wide-ranging education which included the study of history and geography, to which Lady Mary added philosophy, Greek and Latin, as well as other languages which she called 'vehicles of learning' to enable her to read 'books in their originals, that are often corupted and allwaies injur'd by translations' (III:21-2). Mme d'Epinay wished Emilie to have a knowledge of modern and classical literature, mythology and botany, and she also placed strong emphasis on the need for physical exercise, usually in the form of badminton or long walks in the country; ability in needlework was also emphasized. ${ }^{13}$ Above all, each writer wished to communicate to her grandaughter the pleasure of intellectual achievement, the pure joy of reading, of learning for its own sake. Lady Mary wrote: 'No entertainment is so cheap as reading, nor any pleasure so lasting ... The use of knowledge (beside the amusement of solitude) is to moderate the passions and learn to be contented with a small expence' (III:21-2). 
Both writers were convinced that learning could also be a source of consolation to a woman in times of adversity: Mme d'Epinay claimed that 'learning enables one to be free and independent, and to find solace from the injustices of fate and men. ${ }^{14}$ 'I know by experience,' wrote Lady Mary, 'it is in the power of study not only to make solitude tolerable but agreeable' (III:25). Five years later she returned to this theme:

I wish your daughters to ressemble me in nothing but the love of reading, knowing by experience how far it is capable of softening the cruelest accidents of life. Even the happiest cannot be pass'd over without many uneasy hours, and there is no remedy so easy as books, which if they do not give chearfullness at least restore quiet to the most troubled mind. ${ }^{15}$

Mme d'Epinay, like Lady Mary, refused to accept the widely held belief that only boys deserved a good education: ${ }^{16}$ they stressed that when given similar opportunities, girls were equally capable. Mme $\mathrm{d}^{\prime}$ Epinay felt strongly that no limits should be placed on the knowledge to be made available to them, ${ }^{17}$ and that the full range of their talents should be developed at an appropriate time but beginning as early as possible (Emilie could read and write by the age of five). But in a letter to Galiani she lamented the restrictions currently placed by society on the range of subjects considered suitable for study which prevented a woman from becoming a useful member of that society:

Everything connected with administration, politics and commerce is forbidden to her ... she is left with literature, philosophy and art.... But within the fine arts she is forced to renounce sculpture and even painting ... so she is reduced to music, dance and innocent poetry. ${ }^{18}$

At least there had been some improvement since she was a child when a girl's education consisted primarily of preparation for her first communion, some music and dancing, and if she were lucky, a smattering of badly taught history and geography, but rarely any science, which would have been considered out of place, ${ }^{19}$ (although both Fontenelle and Algarotti had encouraged the study of science by women).

Lady Mary's thoughts on the equality of the sexes had evolved considerably over time: as a young lady of twenty-one, she had written to Bishop Burnet:

I am not now arguing for an equality for the 2 sexes; I do not doubt God and Nature has thrown us into an inferior rank. We are the lower part of the Creation; we owe obedience and submission to the superior sex; and any woman who 
suffers her vanity and folly to deny this, rebells against the law of the Creator and indisputable Order of Nature (I:45).

Was this attitude dictated by Burnet's episcopal position or was it simply the result of her surroundings? 'There is no part of the world where our sex is treated with so much contempt as in England,' she declared forty years later from her Italian exile. Indeed, in Italy she was accepted and honoured as an intelligent woman and as an intellectual:

The character of a learned woman is far from being ridiculous in this country, the greatest familys being proud of having produc'd female writers, and a Milanese lady being now proffessor of Mathematics in the University of Bologna (III:39).

By 1753 she felt justified to write 'Nature has not plac'd us in an inferior rank to men, no more than the females of other animals, where we see no distinction of capacity'. But, seemingly aware of the audacity of this statement, she attempted to qualify it by adding:

I could add a great deal on this subject, but I am not now endeavoring to remove the prejudices of Mankind. My only design is to point out to my Grand Daughters the method of being contented with that retreat to which probably their circumstances will oblige them, and which is perhaps preferable to all the show of public Life (III:27).

She admitted that the situation was slowly improving, even in England. In 1756 she wrote 'I congratulate my grand daughters on being born in an age so much enlighten'd ... I do not doubt the frequency of assemblies has introce'd a more enlarg'd way of thinking. It is a kind of public education, which I have allways thought as necessary for girls as boys' (III:106). Mme d'Epinay also felt that it was important to encourage Emilie to meet her friends and participate in parties held at her home, in direct contrast to Rousseau's declared intention of educating Emile away from society.

However, Mme d'Epinay's approach had previously been much more cautious. She had clearly stated in the 1774 edition of the Conversations that a woman's role lay primarily in what she termed '1'économie domestique', guaranteeing the smooth running of the household, of her own affairs and of her children's education. Echoing Rousseau's instructions for Emile's Sophie, she stated that it was a woman's duty to please and be pleasant ('aimable'), and in order to counteract her natural propensity towards flippancy, frivolity, laziness and weakness which were the normal consequences of her education, she should develop the 
habit of serious reflection. But in the 1781 edition she stressed the more positive aspects of Emilie's education and character training which would lead her to be an independent and useful member of society. She wrote that Emilie's education consisted of valuable possessions which no-one could take away from her and which would free her from idleness and dependence on others, even making others dependent on her: the more talents one acquired, the more one became useful and necessary to society (12th Conversation I:467).

To expound theories on the advisability of education for girls was not the aim of either writer but rather to explore the practicality of the proposed education in the specific context of the world in which their grandaughters would grow up. Should they assume that marriage and motherhood were the ultimate goals? Lady Mary did not hesitate to express her scepticism about marriage, and even proposed that the girls should be prepared for spinsterhood. Comparing the purpose of her daughter's and her grandaughter's education, she wrote:

The ultimate end of your education was to make you a good wife...; hers ought to be, to make her happy in a virgin state. I will not say it is happier, but it is undoubtedly safer than any marriage. In a lottery where there is ... ten thousand blanks to a prize, it is the most prudent choice not to venture. (III:24)

Lady Mary's unhappy experience in her own marriage prompted her to take a realistic attitude towards her grandaughter's future and to indicate the hazards of matrimony: her education should not therefore assume the inevitability of marriage. Mme d'Epinay also had an unhappy marriage: a mutual infatuation had prompted her to marry her cousin at the age of 19 but disillusionment quickly followed when she was expecting her first child and she spent most of her life apart from him. Yet she never seemed to question, at least in this first part of the Conversations, whether Emilie's education should prepare her for marriage. For Emilie she forsaw (correctly) a traditional marriage in which she would find fulfilment through her role as wife and mother: to educate her children she must therefore have a good all-encompassing education herself. Near the end of the second volume, in the eighteenth Conversation, a disconcerted Emilie listens to her mother's surprisingly sombre description which contrasts the eternal nature of the marriage commitment with a woman's naturally fickle temperament: echoing her feelings at the outcome of her own ill-fated marriage, Mme d'Epinay warns her that even a happy union can be the cause of untold suffering for the one who is 'condemned to survive'. ${ }^{20}$

Without being as pessimistic as Mme d'Epinay, a sense of realism permeates Lady Mary's thought at all times in her advice to her daugh- 
ter, possibly dictated by her initial reluctance to assume this role. She writes:

People commonly educate their children as they build their houses, according to some plan they think beautifull, without considering whether it is suited to the purposes for which they are design'd. Almost all girls of quality are educated as if they were to be great ladys... You should teach yours to confine their desires to probabilitys, to be as useful as is possible to themselves, and to think privacy (as it is) the happiest state of life. ${ }^{21}$

In the same vein, Mme d'Epinay encouraged Emilie to recognize that her privileged position in society brought with it certain responsibilities towards those less fortunate than herself: acts of charity are strongly encouraged, she is taught to respect and be considerate towards the servants and tradespeople, always without ostentation. One sentence written by Lady Mary in 1756 sums it up: 'Civility costs nothing and buys every thing.' (III:107). Both writers discouraged a preoccupation with beauty, fame or wealth, claiming that these were ephemeral and that 'They should look on these things as blessings where they are bestow'd, tho not necessarys that it is impossible to be happy without', as Lady Mary wrote (II:451). Mme d'Epinay was equally aware of her young charge's propensity to vanity and warned her that true happiness is not found in ephemeral beauty but rather in virtue and strength of character.

Virtue is to be recognized as the real source of happiness; however, Lady Mary warns, 'vices are often hid under the name of virtues... Sincerity, Freindship, Piety, Disinterestness, and Generosity are all great virtues, but persu'd with discretion become criminal' (II:451). The road to virtue lies in study since 'Ignorance is as much the fountain of vice as idleness, and indeed generally produces it' (II:450).

Mme d'Epinay's advice to Emilie on this point is very clear:

When you take the trouble to cultivate your mind and decorate it with solid and useful knowledge, you open up for yourself as many new sources of pleasure and satisfaction; you prepare as many ways of embellishing your life, as many resources against boredom, as much consolation in times of adversity, as you acquire talents and knowledge. No-one can take these away from you and they liberate you from dependence on others since you don't need them to keep yourself busy and to be happy. On the contrary, others come to depend on you; for the more talents you acquire, the more useful and necessary you become to society. (12th conversation, I:467-8)

The value of experience over theories is a cornerstone of the advice of both writers. Lady Mary wrote: 
A Woman marry'd at five and twenty from under the Eye of a strict Parent is commonly as ignorant as she was at five, and no more capable of avoiding the snares or struggling with the Difficulties she will infailllibly meet with in the commerce of the World. The knowledge of mankind (the most usefull of all knowledge) can only be acquir'd by conversing with them (III:106, May 191756).

Because of the many hours spent in each other's company, Mme d'Epinay was able to observe closely Emilie's behaviour, mistakes included. A fall from a ladder inspite of a warning produces bruises and a blow to the vanity but it's all part of the learning experience. Mme d'Epinay used this event to stress the importance of the mother's involvement in her daughter's education: the aim of her book was to share with other mothers her concerns, advice and valuable experience with Emilie, and to encourage them to participate more fully in their daughters' upbringing. She felt it was important to counter the prevailing negative attitude of parents towards their children, perhaps dictated by laziness or indifference to the effects of neglect. This attitude is illustrated with only slight exaggeration by an anecdote entitled La Mauvaise Fille in the fourth Conversation in which a friend of Mlle d'Orville's father is dumbfounded by the idea that he (the father) is prepared to make sacrifices for her:

Leave the pleasures of society for a little girl of seven years! What a strange idea! All she needs is some soup, some tutors; the whip when she argues, a doll so that she will leave you in peace: those are the duties of a father and mother; if they do more they are exceedingly kind. ${ }^{22}$

Mme d'Epinay's approach was to foster trust on the part of the child through a combination of affection, understanding and encouragement, none of which could be developed without willingly spending time together.

A successful education was achieved in part by insisting on absolute honesty in all dealings with the child concerning her abilities. Mme d'Epinay appears almost brutal on occasions in pointing out to Emilie her shortcomings, such as her poor handwriting, vanity, or inadequate embroidery. Lady Mary advised her daughter Lady Bute that she must 'never attempt to govern [her daughters] (as most people do) by Deceit; if they find themselves cheated (even in Triffles) it will ... make them neglect all ... future admonitions.' (II:449, January, 1750). She suggested that 'she accustom them to talk over what they read, and point to them ... the Absurdity often conceal'd under fine expressions' (III:68, July 23 1754). 
The letters containing Lady Mary's advice were directed only to her daughter and grandaughters ... or were they? Were they perhaps also destined for a larger audience? In a letter to her sister she writes 'I assert without the least vanity that [my letters] will be full as entertaining 40 years hence. I advise you therefore to put none of 'em to the use of Wast paper' (II:66, June 1726). Mme d'Epinay expressed indignation when the abbé Galiani reminded her that their correspondence would be published for posterity, claiming that she no longer knew what to write since 'immortality terrifies me'. ${ }^{23}$ Her letters contain in embryo many of the ideas developed in the first edition of the Conversations: although this work was originally published anonymously, many of her readers were aware of the identity of the author. Their encouragement and the success of the first edition inspired her to augment it considerably (the original twelve conversations were expanded to twenty) and to modify the somewhat severe tone, thus making it more accessible to both mothers and their daughters.

How far did the principles proposed by Mme d'Epinay and Lady Mary exceed or coincide with generally accepted ideas on girls' education at that time? Both clearly surpassed their contemporaries in giving such prominence to a girl's education, and in treating her as deserving and capable of a good education. ${ }^{24}$ Mme d'Epinay devoted many years to raising Emilie and to noting her experiences for the benefit of others. Other French women writers, including Mme Lambert, Mme Campan, and Mme de Genlis, had shown similar interest in pedagogy but none had focused so closely on the girl's needs and daily development, nor expressed it in such an accessible and agreeable form as the dialogue between mother and daughter.

Lady Mary's criticism of the educational system in England stands in striking contrast to the traditional acceptance of woman's physical, moral and intellectual inferiority, which only a few feminist voices such as Mary Astell and Mary Wollstonecraft challenged. There were some publications, such as The Ladies' Library, which recommended improving girls' education:

Let them not have so mean an opinion of themselves as to think they are incapable of improving by it [reading]; nor of books, as to think they are incapable of improving by them; there is no lady, let the measure of her understanding be what it will, but may benefit by them; it will add a lustre to her other shining qualities, and help to supply the place of them where such qualities are wanting. (i:14) ${ }^{25}$

But others viewed education as dangerous. In $1773 \mathrm{Mrs}$. Chapone wrote in her Letters on the Improvement of the Mind: 
The danger of pedantry and presumption in a woman ... of her exchanging the graces of imagination for the severity and the preciseness of a scholar, would be, I own, sufficient to frighten me from the ambition of seeing my girl remarkable for learning. (2:121)

The learning which did take place was often superficial and acquired merely as a social advantage. The Lady's Magazine of 1760 informs us that 'To speak French is necessary, in order to appear genteel, more necessary now thought than to be able to read, write, or spell well.' (p.368).

Lady Mary had expressed her thoughts on a woman's role in part 6 of The Nonsense of Common-Sense published anonymously in 1738 . Under the guise of a male writer, she deplores the lack of respect given to the 'fair sex', and recommends recognition of her qualities:

A lady who has perform'd her Duty as a Daughter, a Wife, and a Mother, appears in my Eyes with as much veneration as I should look on Socrates or Xenophon, and much more than I should pay either to Julius Caesar or Cardinal Mazarine ... A Woman realy virtuous in the utmost extent of this expression has virtue of a purer kind than any Philosopher has ever shewn, since she knows if she has Sense (and without it there can be no Virtue) that Mankind is too much prejudice'd against her Sex to give her any Degree of that Fame which is so sharp a spur to their Greatest Actions. ${ }^{26}$

It is difficult to measure the impact these ideas had on their contemporaries or on their families. Lady Mary's ideas were never published other than in their original form as letters to her daughter. Her grandaughters were brought up in a traditional manner, although encouraged to expand their minds. Of all her thirteen grandchildren, only the youngest, Lady Louisa Stuart, showed any real interest in her grandmother's work and distinguished herself as a writer. She wrote a series of biographical anecdotes as an introduction to a collection of the Letters and Works of Lady Mary Wortley Montagu, published in 1836.

At the age of eighteen, Emilie was married to the comte de Bueil, had three children and would have lived an unremarkable, albeit privileged life had not the French Revolution forced her and her children to flee into exile, seeking refuge in Belgium, Holland and Germany and finally at the court of Saxe-Gotha. She took sole responsibility for her children's education and although she did not write anything herself (that we are aware of), her eldest daughter Katinka later wrote Memories of a greatgrandmother from which we learn of the role Emilie played in their survival and education. The impact of Mme d'Epinay's Conversations $d^{\prime}$ Emilie can be measured by its popularity: first published in 1774, the revised version of 1781 had multiple reprintings during the 1780 s and 
two more as late as 1822, and was translated into several languages. It was favourably received by the critics and by the Académie française which awarded Mme d'Epinay its Prix d'Utilité in 1783. Several writers, such as Mme de Staël and Mme Necker, expressed ideas similar to those of Mme d'Epinay, following her death in 1783. By then, girls' education had become a popular theme, taken up vigorously by writers in both England and France. The opinions of Mme d'Epinay and Lady Mary show remarkable similarity, and yet each writer was beset by doubts about the exact form their grandaughters' education should take. We have seen, especially in the case of Mme d'Epinay, how she came to take positions which were diametrically opposite her original convictions. The expression of these doubts is reassuring for the modern reader, conscious of contemporary debates about education on which no agreement can be found. We can only applaud the courage of both Lady Mary and Mme d'Epinay to express in a generally hostile environment ideas which clashed with the widely held belief that girls' education was unimportant, but which inspired others to pursue the same struggle.

\author{
ROSENA DAVISON \\ Simon Fraser University
}

\title{
Notes
}

1 All passages from Lady Mary's correspondence are taken from Robert Halsband's edition (Oxford: Clarendon, 1967) and the original spelling has been respected. On both sides of the Channel many writers gave expression to the inadequacy of the education given to women, and to the deplorable results. Thus Mme de Graffigny wrote in her Lettres d'une Péruvienne (1747): 'L'éducation qu' on leur donne [aux femmes] est si opposée à la fin qu'on se propose, qu'elle me paraît être le chef-d'oeuvre de l'inconséquence française' (Flammarion, 1983, p.341). ['The education given to women is so far removed from the aim one proposes that it strikes me as being a masterpiece of French inconsistency']. All translations are my own.

2 Letter to Galiani dated January 4, 1771. Louise d'Epinay and Ferdinando Galiani, Correspondance, ed. Daniel Maggetti (Paris: Desjonquères, 1993) II:24.

3 Her published works are Mes Moments heureux (in which she sketched her ideas on the education of her children), Histoire de Mme de Montbrillant (her semi-fictitious memoirs), Les Conversations $d^{\prime}$ Emilie, several contributions to Grimm's Correspondance littéraire, and her Mémoires et correspondance. Recognizing her talents, Voltaire called her 'an eagle in a gauze cage.'

4 He described her as 'une des femmes d'Angleterre qui a le plus d'esprit et le plus de force dans l'esprit' (Lettre XI, Lettres philosophiques). 
5 Anita Desai, Introduction to the Turkish Embassy Letters (Athens: University of Georgia Press, 1993) xx.

6 Robert Halsband, The Life of Lady Mary Wortley Montagu (Oxford: Clarendon, 1957) 5 .

7 Desai $x$.

8 Lettre à mon fils and Lettre à la gouvernante de ma fille appeared as part of a book entitled Mes Moments heureux.

9 She initially expressed the conviction that private tutoring was too precarious since the child's education could be threatened by the departure of one person (Les Conversations d'Emilie [Paris: Belin, 1782] II:271). She also felt that she lacked the confidence to stray from well known paths tried by others in public institutions (II:452). However, in the final Conversation she concluded that private education, with all its imperfections, was still preferable to the unknown elements of a public education over which she had no control: 'Après bien des incertitudes, j'ai préféré l'inconvénient d'une éducation particulière, presque toujours triste, maniérée et décousue, à celui d'une éducation publique que je ne pouvais ni approuver ni corriger' (II:464).

10 Letter dated March 61753 (III:26).

11 12th Conversation I:467. Earlier, in the 10th Conversation she had written: 'Nothing makes one as happy as keeping busy, nothing makes one as sad as idleness' ['Rien ne rend heureux comme l'occupation, rien ne rend triste comme l'oisiveté'] (I:347).

12 Letter to Lady Bute, March 61753 (III:26).

13 'I think it is as scandalous for a Woman not to know how to use a needle, as for a Man not to know how to use a sword' declared Lady Mary (III:23, January 28 1753).

14 Letter dated January 41771 to the abbe Galiani (Correspondance, ed. Mazzetti, II:26)

15 Letter to Lady Bute dated May 31758 (III:144).

16 Both Mme d'Epinay and Lady Mary were very disillusioned with their sons, who had turned out to be useless scoundrels who brought shame on the family and had to be rescued on several occasions from debts and prison.

17 'Je ne me permets point de fixer les bornes du savoir des personnes de notre sexe' (12th Conversation, I:442).

18 Correspondance II:25-6. Perhaps she is accepting defeat by admitting at the end of the Conversations that women are limited by their 'weakness' to carrying out domestic duties which are all that society expects from them: 'La faiblesse de notre sexe et la sphère étroite de nos petits talents nous confinent dans l'exercice des devoirs domestiques: en les remplissant, nous avons satisfait à tout ce que la société attend de nous' (20th Conversation, II:430).

19 12th Conversation (I:442-3). She adds, 'Surtout on ne nous parlait jamais raison; et quant à la science, on la trouvait très déplacée dans les personnes de notre sexe, et l'on évitait avec soin toute espèce d'instruction.' ['No-one ever spoke to us about reason; and as for science, it was considered very out of place in persons of our sex, and all instruction was carefully avoided']. Here she is acknowledging what the situation used to be at the beginning of the eighteenth century, whereas Lady Mary writes of a situation which she believes to be current in England. 
20 'Ce jour vous fait d'ailleurs contracter un engagement éternel. Cela ne vous paraît-il pas redoutable pour des êtres si faibles, si variables, si inconstants, si fugitifs, si passagers? Un engagement éternel qu'il n'est plus possible de rompre quelles qu'en soient les suites. Si cet engagement devient malheureux, c'en est fait du bonheur de toute la vie; s'il est heureux, son commencement vous avertit dès à présent et même malgré vous, de sa fin, puisque tout ce qui commence doit nécessairement finir. L'inexorable loi à qui tout est soumis, vous entraînera dès cet instant, progressivement vers le terme de cette union si tendre, sur laquelle le bonheur de votre vie etait fondé, et plongera dans les regrets et dans les larmes celui des deux qu'elle aura condamné à survivre.' II:321-2.

21 Letter of February 191950 to Lady Bute (II:450).

22 'Quitter tous les agréments de la société pour une petite fille de sept ans! Quelle extravagance! On donne à cela de la soupe, des maîtres; le fouet quand cela s'avise de raisoner, une poupée pour qu'elle vous laisse en repos: voilà à quoi père et mère sont obligés; quand ils font davantage ils ont bien de la bonté' (I:75-6).

23 'Voilà à présent que je ne sais plus que vous dire: l'immortalité me fait une peur épouvantable.' Letter dated June 26 1773, Gli ultimi anni della signora d'Epinay: lettere inedite all'abate Galiani 1773-82, ed. F. Nicolini (Bari: Laterza, 1933) 38.

24 This is how Ruth Perry describes the effects of poor education for women in England: 'This inattention to women's education is attested to by the shocking illiteracy among even the upper class women who could afford to buy books ... Learning was so unusual in a woman as to be thought of as out of place. The culture even dictated that women be proud of their ignorance; it was part of the image of femininity.' Women, Letters and the Novel (New York: AMS, 1980) 44-5.

25 Quoted by Jacques Carré in his article 'La littérature de civilité et la condition des femmes au XVIIIle siècle,' Etudes Anglaises 47 (1994): 17.

26 Lady Mary Wortley Montagu, Essays and Poems, edited by Robert Halsband and Isobel Grundy (Oxford: Clarendon, 1977) 133-4. 